\title{
Effect of bacterial endophytes - Azospirillum brasilense and Pseudomonas fluorescens on growth and yield of Brinjal var. Annamalai in field trial
}

\author{
${ }^{*} \mathrm{U}$. Sivagamasundari ${ }^{* *}$ and Dr. A. Gandhi ${ }^{2}$ \\ aDepartment of Botany, Annamalai University, Tamilnadu, India \\ ${ }^{\mathrm{b}}$ Kristu Jayanti College (Autonomous), Bangalore, Karnataka, India. \\ ${ }^{*}$ Corresponding Author email: sundariutharanan@gmail.com
}

\begin{abstract}
The trial was carried out in agriculture field, Karaikal during the season of June- September to test the efficacy of isolated bacterial endophytes from the roots of brinjal as microbial inoculants in seeds along with inorganic fertilizers in soil on growth, yield and some biochemical constitutions of brinjal (Solanum melongena L.) and considering the growth, yield and the biochemical constitutions, the data revealed that maximum parameters were recorded in $\mathrm{T}_{6}$ and The results showed that the application of microbial inoculants and inorganic fertilizers and their combinations significantly influenced the growth, yield, quality and biochemical contents of brinjal. The mixed application of $100 \%$ Chemical fertilizer with combination of Azospirillum brasilense and Pseudomonas fluorescens received best performance of brinjal compared to other treatments.
\end{abstract}

Keywords Endophytes; Microbial inoculants; brinjal; Azospirillum brasilense and Pseudomonas fluorescens.

\section{Introduction}

Different kinds of microorganisms, including fungi, actinomycetes and bacteria have been found inside the plants and designated as endophytes. It inhabits plant tissues in their life cycle without causing any apparent harm to their host. These bacteria, that generally colonize the intercellular spaces, have been isolated from all plant tissues and from many plant species constituting a great reservoir of bacterial diversity with a remarkable biotechnological potential (Ulrich et al., 2008). Endophytic bacteria have been found in virtually every plant studied, where they colonize in the internal tissues of their host plant and can form a range of different relationships including symbiosis, mutualism, neutralism and commensalism. A diverse array of bacterial species has been reported to be endophytic including Acetobacter, Arthrobacter, Bacillus, Burkholderia, Enterobacter, Herbaspirillum and Pseudomonas (Lodewyckz et al., 2002). In recent years various novel endophytic nitrogen-fixing bacteria have been discovered, such as Acetobacter seropedicae (Cavalcante and Dobereiner, 1998), Herbaspirillum serepedicae (Baldiani et al., 1986), and "Pseudomonas", now established as a second species of Herbaspirillum, Azoarcus spp. (Reinhold-Hurek et al., 1993) and Alcaligenes faecalis (Zhou and you, 1988). Also, some strains of Azospirillum brasilense have been found to the plant interior (Schloter et al., 1994).

\subsection{Endophytic colonization}

Plant beneficial microorganisms are of interest for application in agriculture either as biofertilizers or as pesticides as well as for phytoremediation applications (Sturz et al., 2000; Berg, 2009; Lugtenberg and Kamilova, 2009; Weyens et al., 2009). Takuma Gamo and Sang Bae Ahn et al., 2013 reported effective colonization and increasing acetylene reduction in Azospirillum sp. isolated from several non-graminous crops. Steenhoudt and Vanderleyden, 2000 reported, Azospirillum, a free-living nitrogen-fixing bacterium closely associated with grasses. Ivan et al., 1997 observed, biological nitrogen fixation in non-leguminous field crops, facilitating the evolution of an effective association between Azospirillum and wheat. Therefore, not only mechanisms responsible for plant growth promotion have to be investigated, but also a thorough understanding of all steps involved in plant colonization by PGPB is required to improve the efficiency and reliability of inoculant strains. In the last decade it has been repeatedly demonstrated that the plant interior is colonized by a range of endophytes mostly deriving from the rhizosphere and many of them have been reported to improve plant growth or health (Sturz and Nowak, 2000; Hardoim et al., 2008).

In the present investigation endophytic nitrogen fixing bacteria were isolated from brinjal. Among the major food crops, vegetables are the most important one by cultivation and consumption in India, particularly in Tamilnadu. Vegetables are nowadays in daily supplements in a variety of ways, as part of main meals and as snacks. As nitrogen is the major element required for its production, focusing on isolation and identification of effective nitrogen fixing bacteria for increasing growth and yield with reduction of the hazardous fertilizer nitrogen use is being an essential need. Most of the studies have explored the properties of these isolates in relation to their as agronomical inoculants fixing bacterial community that inhabits particularly with vegetables has been poorly studied. (Fig 1)

Brinjal or eggplant (Solanum melongena L.) is an important solanaceous crop of sub-tropics and tropics. it is commercial vegetable crops grown all over India for its high nutritive value and enumerative price India ranks first both in area (5.1 lakh ha) and production (88 lakh MT) (Anonymous, 2004). The name brinjal is popular 


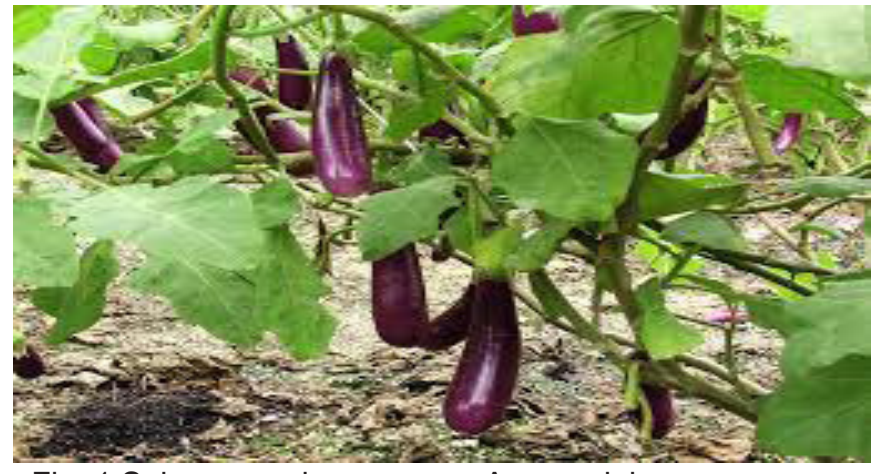

Fig: 1 Solanum melongena var. Annamalai

in Indian subcontinents and is derived from Arabic and Sanskrit whereas the name eggplant has been derived from the shape of the fruit of some varieties, which are white and resemble in shape to chicken eggs. It is known to have ayurvedic medicinal properties and is good for diabetic patients. It has also been recommended as an excellent remedy for those suffering from liver complaints (Shukla and Naik 1993). By keeping its wide cultivation in India and healthy nutrient diet, it has planned to study the effect of endophytic nitrogen fixing bacterial species on growth and yield of brinjal.

\section{Materials and methods}

\subsection{Collection of seeds}

Brinjal var. Annamalai was received from the Department of Horticulture, Faculty of Agriculture, Annamalai University, Annamalai nagar.

\subsection{Inoculant preparation}

Nitrogen free liquid medium was prepared for $A$. brasilense and King's $B$ liquid medium for $P$. fluorescens were prepared, the cultures were inoculated and kept for $48 \mathrm{hrs}$ in rotary shaker at $32^{\circ} \mathrm{C}$. After shaking, the density of the culture was observed by turbidity and the population test was carried out by standard method and applied as seed inoculation.

\subsection{Seed treatment with bacterial endophytes}

The most common way of inoculation is "seed inoculation", in which the grown effective bacterial isolates of $A$. brasilense and $P$. fluorescens were mixed with seeds. $2 \mathrm{gms}$ of brinjal seeds was treated with $1.5 \mathrm{ml}$ of $A$. brasilense and $P$. fluorescens broth as individual and dual form according to the treatment given below. The untreated seeds were maintained as control. The treated seeds were shade dried and immediately sown in proplates at rate of one seed in each cup, containing cocopeat as substrate. (Fig 2)

\section{Field trial}

The trial was carried out in a randomized block design in cultivable land, Karaikal during the season of June to September 2014, with seven treatments and three replications. Immediately after uprooting of 30 days old seedlings from proplates, the roots of the seedlings

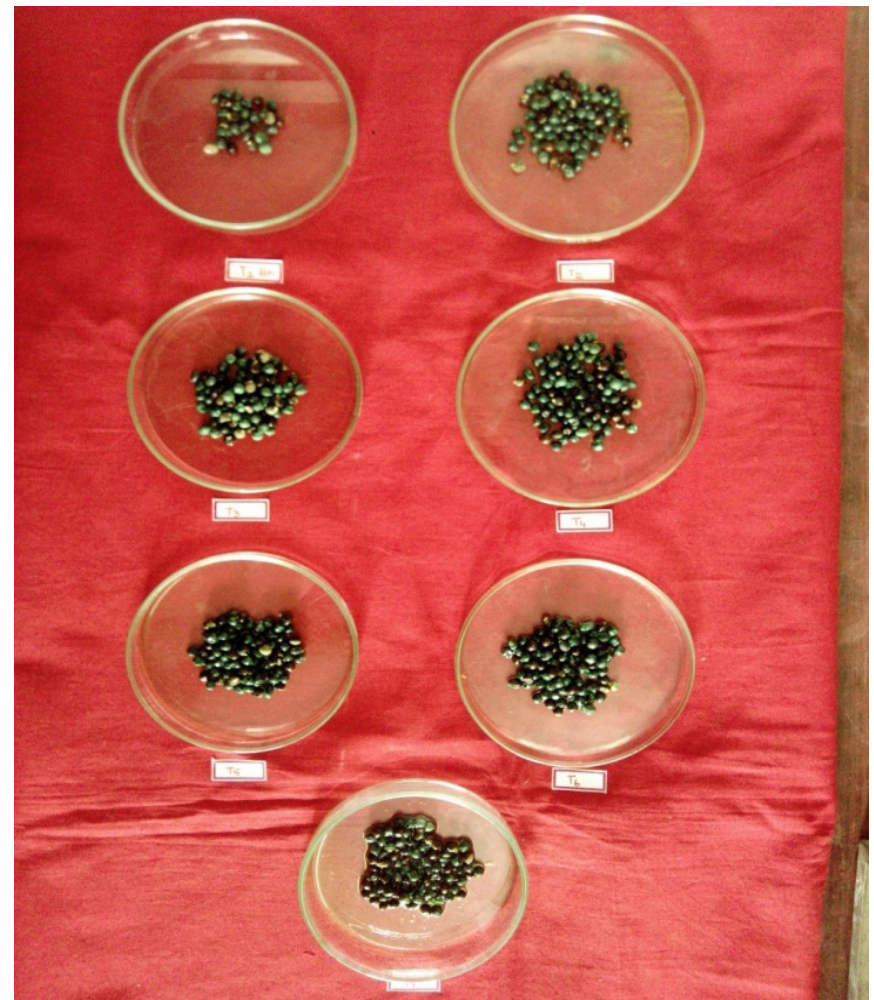

Fig: 2 Seed Treatment

with cocopeat were dipped in solution prepared with $A$. brasilense and $P$. fluorescens cultures as per treatments for 60 seconds. Then the seedlings of bhendi from proplates was transplanted at the rate of two seedlings per hill with spacing of $75 \mathrm{~cm}$ for brinjal between rows and plants respectively in field as per treatments and irrigation was done. Five seedlings were planted per pot as per the treatments and irrigated immediately.

\subsection{Treatments}

$\mathrm{T}_{1}-100 \%$ Chemical fertilizer (Control)

$\mathrm{T}_{2}-100 \%$ Chemical fertilizer + Azospirillum brasilense

$\mathrm{T}_{3}-75 \%$ Chemical fertilizer + Azospirillum braziliense

$\mathrm{T}_{4}-100 \%$ Chemical fertilizer + Pseudomonas fluorescens

$\mathrm{T}_{5}-75 \%$ Chemical fertilizer + Pseudomonas fluorescens

$\mathrm{T}_{6}-100 \%$ Chemical fertilizer + Azospirillum braziliense + Pseudomonas fluorescens

$\mathrm{T}_{7}-75 \%$ Chemical fertilizer + Azospirillum braziliense + Pseudomonas fluorescens

\subsection{Replications: 3 Nos. in each.}

Chemical fertilizers: Recommended dosages of NPK for brinjal N-100 kg/ha, P-50 kg/ha, K-30 kg/ha

\section{Biometric observations}

Three plants from each treated plot were selected at random to observe the following growth and yield parameters. 


\subsubsection{Growth parameters}

\section{Shoot length}

The selected plants were used for measuring shoot length in centimetres from the base of plant to the terminal growing point of the plant at $30^{\text {th }}, 60^{\text {th }}$ and $90^{\text {th }}$ day after transplanting (DAT).

\section{Root length}

The selected plants were used for measuring root length in centimetres from the base of plant to the tip of the longest root at $30^{\text {th }}, 60^{\text {th }}$ and $90^{\text {th }}$ day after transplanting (DAT).

\section{Leaf chlorophylls content (Arnon's 1949)}

$100 \mathrm{mg}$ of leaves was grounded in a mortar and pestle with $20 \mathrm{ml}$ of $80 \%$ acetone. The homogenate was centrifuged at $3000 \mathrm{rpm}$ for 15 minutes. The clear supernatant was saved. The pellet was a re-extracted with $5 \mathrm{ml}$ of $80 \%$ acetone each time, until it became colourless. All the supernatant was pooled and was utilized for chlorophyll determination. Absorbance was read at $645 \mathrm{~nm}$ and $663 \mathrm{~nm}$ in spectrophotometer 20.

\section{Number of leaves per plant} $90^{\text {th }}$ DAT.

The number of leaves was counted at $30^{\text {th }}, 60^{\text {th }}$ and

\section{Total number of branches per plant}

The number of branches was counted at $30^{\text {th }}, 60^{\text {th }}$ and $90^{\text {th }}$ DAT.

\section{Number of flowers}

The plants were observed for number of flowers appeared in each treatment at $30^{\text {th }}, 60^{\text {th }}$ and $90^{\text {th }}$ DAT.

\subsubsection{Yield parameters}

\section{Number of fruits per plant}

The mean fruit number per plant was counted from the total number of fruits harvested at $30^{\text {th }}, 60^{\text {th }}$ and $90^{\text {th }}$ DAT.

\section{Fruit weight (g)}

Fruit weight was weighed individually in each treatment at $30^{\text {th }}, 60^{\text {th }}$ and $90^{\text {th }}$ DAT.

\section{Fruit length (cm)}

Length of the fruits was measured individually in centimeters from the base of calyx to tip of fruit using Vernier Calipers and the average was calculated at regular intervals.

\section{Fruit girth (cm)}

Fruit girth was measured by using Vernier Calipers and later average was worked out and expressed in centimeters.

\section{Number of seeds per fruit}

In each treatment, number of seeds per fruit was counted manually and their average was expressed as mean number of seeds per fruit.

\subsubsection{Biochemical constitutions of fruit}

Total moisture and Total ash (Lab Manual 5: fssai, Manual methods of analysis of foods for fruits and vegetables), Protein (Lowry et al., 1951), Flavonoids (Jagadish et al., 2009), Total sugars (Nelson, 1944), Total Anthocyanin measurement (Christopher Beggs and Wellman, 1985), Total phenolic content (Jagadish et al., 2009) and Ascorbic acid content (Vitamin ' $C$ ') (Omaye, 1979) and antioxidant enzymes (Kumar and Khan, 1982) were estimated.

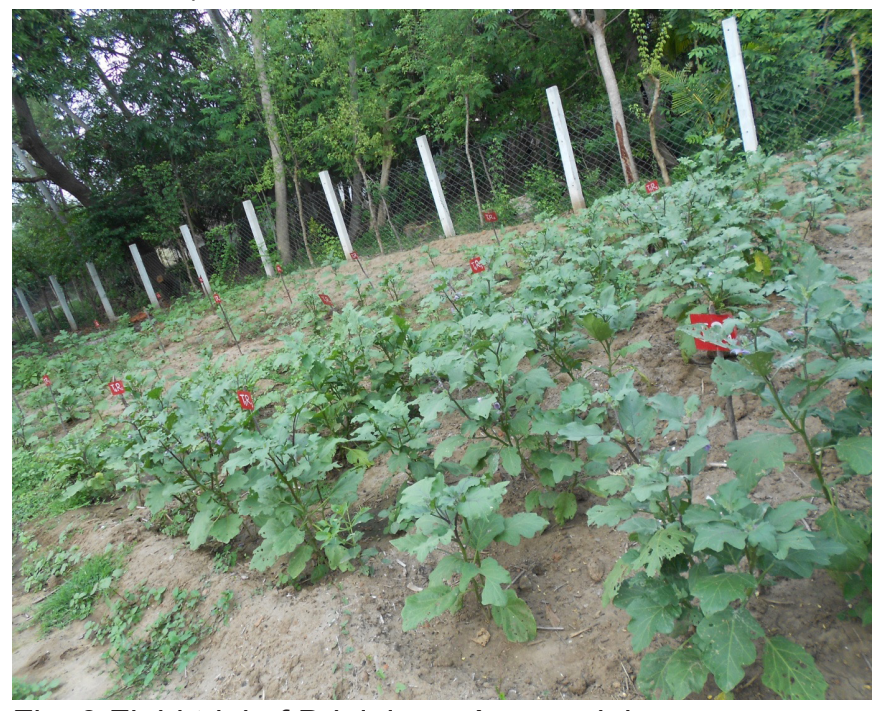

Fig: 3 Field trial of Brinjal var. Annamalai

\section{Results}

The results indicated significant difference among the kinds of biofertilizers and their combinations with inorganic fertilizers. The inoculation with bacterial treatments had a more stimulating effect on growth and development of plants in nonsterile soil than sterile condition. Seed inoculation with elite endophytic nitrogen fixing bacterial strains significantly enhanced seed germination, growth and yield of brinjal.

Here combined seed inoculation with 100\% chemical fertilizer with Azospirillum brasilense and Pseudomonas fluorescens was found superior to other combinations. similarly, biochemical constitutions of fruit like total moisture, total ash, protein, flavonoids, total sugars, total phenols, anthocyanin and vitamin ' $\mathrm{C}$ ' (ascorbic acid) have also shown maximum contents in combined inoculation of $75 \%$ chemical fertilizer with Azospirillum brasilense and Pseudomonas fluorescens followed by other combinations compared with control.

The increase in growth characters might be due to the fact that the Azospirillum inoculated plants were able to absorb nutrients from solution at faster rates 
10.5530/ctbp.2021.3s.44

Table 1. Effect of efficient isolates of Azospirillum sp. and Pseudomonas sp. on shoot and root length of brinjal in field experiment.

\begin{tabular}{|c|c|c|c|c|c|c|}
\hline \multirow{2}{*}{ Treatments } & \multicolumn{3}{|c}{ Shoot Length (cm) } & \multicolumn{3}{c|}{ Root Length (cm) } \\
\cline { 2 - 7 } & $\mathbf{3 0}$ DAYS & $\mathbf{6 0}$ DAYS & 90 DAYS & $\mathbf{3 0 ~ D A Y S}$ & 60 DAYS & 90 DAYS \\
\hline $\mathrm{T}_{1}$ & $10.27 \pm 0.0754$ & $21.28 \pm 0.0305$ & $32.99 \pm 0.0360$ & $9.82 \pm 0.0404$ & $13.45 \pm 0.0602$ & $13.09 \pm 0.0458$ \\
\hline $\mathrm{T}_{2}$ & $12.19 \pm 0.0351$ & $22.26 \pm 0.0360$ & $42.15 \pm 0.0208$ & $12.09 \pm 0.0360$ & $17.20 \pm 0.0550$ & $15.29 \pm 0.0585$ \\
\hline $\mathrm{T}_{3}$ & $12.37 \pm 0.0264$ & $28.66 \pm 0.0208$ & $47.32 \pm 0.0305$ & $11.61 \pm 0.0404$ & $16.89 \pm 0.0493$ & $17.16 \pm 0.0450$ \\
\hline $\mathrm{T}_{4}$ & $10.56 \pm 0.0305$ & $23.16 \pm 0.0305$ & $37.62 \pm 0.0152$ & $10.78 \pm 0.0435$ & $15.12 \pm 0.0251$ & $16.08 \pm 0.0550$ \\
\hline $\mathrm{T}_{5}$ & $10.41 \pm 0.0321$ & $25.30 \pm 0.0351$ & $42.22 \pm 0.0208$ & $11.68 \pm 0.0416$ & $16.66 \pm 0.0305$ & $15.06 \pm 0.0351$ \\
\hline $\mathrm{T}_{6}$ & $16.21 \pm 0.0264$ & $32.83 \pm 0.0251$ & $56.18 \pm 0.0305$ & $12.87 \pm 0.0404$ & $15.66 \pm 0.0709$ & $16.82 \pm 0.0360$ \\
\hline $\mathrm{T}_{7}$ & $14.16 \pm 0.0264$ & $30.26 \pm 0.0264$ & $53.12 \pm 0.0351$ & $12.74 \pm 0.0450$ & $14.70 \pm 0.0450$ & $15.77 \pm 0.0472$ \\
\hline
\end{tabular}

Values are mean \pm S.D of three samples of $\mathrm{mg} / \mathrm{g}$ of fresh weight

Table 2. Effect of efficient isolates of Azospirillum sp. and Pseudomonas sp. on Chlorophyll content of leaves of brinjal in field experiment.

\begin{tabular}{|c|c|c|c|c|c|c|c|c|c|}
\hline \multirow{2}{*}{ Treatments } & \multicolumn{3}{|c}{ Chlorophyll ' $a$ ' } & \multicolumn{3}{c|}{ Chlorophyll 'b' } & \multicolumn{3}{c|}{ Total Chlorophyll } \\
\cline { 2 - 10 } & $\mathbf{3 0}$ DAYS & $\mathbf{6 0}$ DAYS & $\mathbf{9 0}$ DAYS & $\mathbf{3 0}$ DAYS & $\mathbf{6 0}$ DAYS & $\mathbf{9 0}$ DAYS & 30 DAYS & 60 DAYS & 90 DAYS \\
\hline $\mathrm{T}_{1}$ & $0.76 \pm 0.0503$ & $1.26 \pm 0.0702$ & $1.62 \pm 0.0360$ & $0.28 \pm 0.0321$ & $0.79 \pm 0.0305$ & $1.32 \pm 0.0351$ & $1.55 \pm 0.0655$ & $2.31 \pm 0.0458$ & $3.77 \pm 0.0602$ \\
\hline $\mathrm{T}_{2}$ & $1.18 \pm 0.0321$ & $1.37 \pm 0.0360$ & $1.73 \pm 0.1026$ & $0.57 \pm 0.0360$ & $1.06 \pm 0.0208$ & $2.04 \pm 0.0450$ & $1.17 \pm 0.0360$ & $3.27 \pm 0.0503$ & $3.34 \pm 0.0550$ \\
\hline $\mathrm{T}_{3}$ & $1.03 \pm 0.0305$ & $1.58 \pm 0.0305$ & $1.86 \pm 0.0458$ & $0.49 \pm 0.0305$ & $0.79 \pm 0.0493$ & $1.48 \pm 0.0611$ & $1.13 \pm 0.0208$ & $2.80 \pm 0.0351$ & $3.16 \pm 0.0458$ \\
\hline $\mathrm{T}_{4}$ & $1.00 \pm 0.0351$ & $1.46 \pm 0.0450$ & $1.82 \pm 0.0351$ & $0.38 \pm 0.0264$ & $0.69 \pm 0.0404$ & $1.34 \pm 0.0503$ & $0.84 \pm 0.0305$ & $2.64 \pm 0.0351$ & $2.20 \pm 0.0529$ \\
\hline $\mathrm{T}_{5}$ & $0.87 \pm 0.0513$ & $1.32 \pm 0.0351$ & $1.64 \pm 0.0556$ & $0.32 \pm 0.0305$ & $0.88 \pm 0.0351$ & $1.28 \pm 0.0503$ & $1.75 \pm 0.0964$ & $2.44 \pm 0.0351$ & $4.25 \pm 0.0650$ \\
\hline $\mathrm{T}_{6}$ & $1.47 \pm 0.0602$ & $1.62 \pm 0.0450$ & $2.03 \pm 0.0458$ & $1.14 \pm 0.0152$ & $1.67 \pm 0.0378$ & $2.22 \pm 0.0351$ & $3.14 \pm 0.0351$ & $3.79 \pm 0.0458$ & $4.21 \pm 0.0351$ \\
\hline $\mathrm{T}_{7}$ & $1.39 \pm 0.0585$ & $1.64 \pm 0.0360$ & $2.07 \pm 0.0416$ & $1.10 \pm 0.0305$ & $1.55 \pm 0.0351$ & $2.14 \pm 0.0264$ & $2.94 \pm 0.0416$ & $3.72 \pm 0.0503$ & $2.94 \pm 0.0650$ \\
\hline
\end{tabular}

Values are mean \pm S.D of three samples of $\mathrm{mg} / \mathrm{g}$ of fresh weight

Table 3. Effect of efficient isolates of Azospirillum sp. and Pseudomonas sp. on number of leaves, branches and flowers/ plant of brinjal in field experiment.

\begin{tabular}{|c|c|c|c|c|c|c|c|c|c|}
\hline \multirow{2}{*}{ Treatments } & \multicolumn{3}{|c|}{ Number of Leaves/Plant } & \multicolumn{3}{|c|}{ Number of Branches/Plant } & \multicolumn{3}{|c|}{ Number of Flowers/Plant } \\
\hline & 30 DAYS & 60 DAYS & 90 DAYS & $\begin{array}{c}\text { 30 } \\
\text { DAYYS }\end{array}$ & 60DAYS & 90 DAYS & $\begin{array}{c}30 \\
\text { DAYS }\end{array}$ & 60 DAYS & 90 DAYS \\
\hline $\mathrm{T}_{1}$ & $4.00 \pm 0.0305$ & $12.36 \pm 0.0305$ & $20.06 \pm 0.0305$ & 0 & 0 & $3.06 \pm 0.0305$ & 0 & $4.89 \pm 0.0351$ & $12.29 \pm 0.0351$ \\
\hline $\mathrm{T}_{2}$ & $5.09 \pm 0.0264$ & $14.47 \pm 0.0360$ & $22.22 \pm 0.0360$ & 0 & $1.77 \pm 0.0360$ & $4.71 \pm 0.0458$ & 0 & $7.52 \pm 0.0360$ & $18.23 \pm 0.0251$ \\
\hline $\mathrm{T}_{3}$ & $5.18 \pm 0.0378$ & $15.12 \pm 0.0251$ & $24.36 \pm 0.0305$ & 0 & $2.12 \pm 0.0251$ & $3.25 \pm 0.0450$ & 0 & $8.05 \pm 0.0208$ & $18.70 \pm 0.0360$ \\
\hline $\mathrm{T}_{4}$ & $4.38 \pm 0.0378$ & $14.45 \pm 0.0251$ & $20.44 \pm 0.0251$ & 0 & 0 & $3.18 \pm 0.0702$ & 0 & $6.78 \pm 0.0321$ & $15.87 \pm 0.0360$ \\
\hline $\mathrm{T}_{5}$ & $4.12 \pm 0.0208$ & $15.10 \pm 0.0251$ & $22.10 \pm 0.0305$ & 0 & $2.00 \pm 0.0321$ & $4.29 \pm 0.0450$ & 0 & $7.00 \pm 0.0305$ & $19.00 \pm 0.0458$ \\
\hline $\mathrm{T}_{6}$ & $7.22 \pm 0.0264$ & $16.10 \pm 0.0351$ & $29.18 \pm 0.0360$ & 0 & $3.16 \pm 0.0305$ & $5.00 \pm 0.0450$ & 0 & $9.16 \pm 0.0351$ & $23.08 \pm 0.0378$ \\
\hline $\mathrm{T}_{7}$ & $6.36 \pm 0.0208$ & $15.22 \pm 0.0152$ & $26.23 \pm 0.0305$ & 0 & $3.12 \pm 0.0305$ & $3.88 \pm 0.0435$ & 0 & $8.35 \pm 0.0251$ & $20.63 \pm 0.0152$ \\
\hline
\end{tabular}

Values are mean \pm S.D of three samples of $\mathrm{mg} / \mathrm{g}$ of fresh weight 
$10.5530 /$ ctbp. $2021.3 s .44$

Table 4. Effect of efficient isolates of Azospirillum sp. and Pseudomonas sp. on yield parameters of brinjal in field experiment.

\begin{tabular}{|c|c|c|c|c|c|c|}
\hline \multirow{2}{*}{ Treatments } & $\begin{array}{c}\text { Number of } \\
\text { Fruits/Plant }\end{array}$ & $\begin{array}{c}\text { Fruit Weight } \\
\text { (gm) }\end{array}$ & $\begin{array}{c}\text { Fruit Length } \\
\text { (cm) }\end{array}$ & $\begin{array}{c}\text { Fruit Girth } \\
\text { (cm) }\end{array}$ & $\begin{array}{c}\text { Number of } \\
\text { Seeds/Fruit }\end{array}$ & $\begin{array}{c}\text { Average Fruit } \\
\text { Yield/Plot }\end{array}$ \\
\hline $\mathrm{T}_{1}$ & $11.21 \pm 0.0152$ & $6.06 \pm 0.0351$ & $8.15 \pm 0.0208$ & $130.09 \pm 0.0208$ & $1317.17 \pm 0.0360$ & $5.27 \pm 0.0472$ \\
\hline $\mathrm{T}_{2}$ & $11.30 \pm 0.0305$ & $7.08 \pm 0.0152$ & $9.10 \pm 0.0503$ & $133.56 \pm 0.0264$ & $1436.02 \pm 0.0404$ & $7.42 \pm 0.0351$ \\
\hline $\mathrm{T}_{3}$ & $12.16 \pm 0.0360$ & $6.14 \pm 0.0173$ & $8.46 \pm 0.0416$ & $130.14 \pm 0.0251$ & $1334.07 \pm 0.0360$ & $6.24 \pm 0.0606$ \\
\hline $\mathrm{T}_{4}$ & $12.27 \pm 0.0305$ & $6.12 \pm 0.0264$ & $8.70 \pm 0.0513$ & $140.18 \pm 0.0251$ & $1429.24 \pm 0.0251$ & $6.17 \pm 0.0251$ \\
\hline $\mathrm{T}_{5}$ & $11.38 \pm 0.0416$ & $7.06 \pm 0.0251$ & $8.78 \pm 0.0416$ & $135.34 \pm 0.0251$ & $1589.34 \pm 0.0305$ & $7.27 \pm 0.0513$ \\
\hline $\mathrm{T}_{6}$ & $13.19 \pm 0.0351$ & $7.21 \pm 0.0208$ & $9.09 \pm 0.0351$ & $147.16 \pm 0.0305$ & $1607.19 \pm 0.0067$ & $8.09 \pm 0.0351$ \\
\hline $\mathrm{T}_{7}$ & $13.12 \pm 0.0264$ & $7.18 \pm 0.0305$ & $8.91 \pm 0.0351$ & $138.23 \pm 0.0305$ & $1433.06 \pm 0.0251$ & $8.02 \pm 0.0458$ \\
\hline
\end{tabular}

Values are mean \pm S.D of three samples of $\mathrm{mg} / \mathrm{g}$ of fresh weight

Table 5. Effect of efficient isolates of Azospirillum sp. and Pseudomonas sp. on biochemical constituents of fruits of brinjal at harvest in field experiment.

\begin{tabular}{|c|c|c|c|c|c|c|c|c|c|}
\hline Treatments & $\begin{array}{c}\text { Total } \\
\text { Moisture } \\
\mathbf{( \% )}\end{array}$ & $\begin{array}{c}\text { Total Sugar } \\
\mathbf{( m g / g m})\end{array}$ & $\begin{array}{c}\text { Total ash } \\
\mathbf{( \% )}\end{array}$ & $\begin{array}{c}\text { Total } \\
\text { Phenols } \\
(\mathbf{m g} / \mathbf{g m})\end{array}$ & $\begin{array}{c}\text { Protein } \\
(\mathbf{m g} / \mathbf{g m})\end{array}$ & $\begin{array}{c}\text { Anthocyanin } \\
(\mathbf{m g} / \mathbf{1 0 0 g m ~ o f ~} \\
\mathbf{p e e l})\end{array}$ & $\begin{array}{c}\text { Ascorbic acid } \\
\mathbf{( \% )}\end{array}$ & $\begin{array}{c}\text { Peroxidase } \\
\mathbf{( m g} / \mathbf{g m})\end{array}$ & $\begin{array}{c}\text { Polyphenol } \\
\text { Oxiodase } \\
(\mathbf{m g} / \mathbf{g m})\end{array}$ \\
\hline $\mathrm{T}_{1}$ & $80 \pm 4.163$ & $3.75 \pm 0.0305$ & $0.35 \pm 0.043$ & $4.20 \pm 0.0305$ & $0.61 \pm 0.0251$ & $0.036 \pm 0.0171$ & $4.835 \pm 0.003$ & $4.12 \pm 0.0305$ & $4.45 \pm 0.0208$ \\
\hline $\mathrm{T}_{2}$ & $85 \pm 7.637$ & $5.10 \pm 0.0351$ & $0.52 \pm 0.035$ & $5.02 \pm 0.0351$ & $0.84 \pm 0.0251$ & $0.052 \pm 0.0072$ & $7.335 \pm 0.003$ & $4.83 \pm 0.0208$ & $5.03 \pm 0.0251$ \\
\hline $\mathrm{T}_{3}$ & $85 \pm 2.156$ & $5.50 \pm 0.0416$ & $0.44 \pm 0.045$ & $5.05 \pm 0.0152$ & $0.73 \pm 0.0264$ & $0.048 \pm 0.0053$ & $6.914 \pm 0.007$ & $5.26 \pm 0.0305$ & $5.48 \pm 0.0305$ \\
\hline $\mathrm{T}_{4}$ & $88 \pm 8.386$ & $5.17 \pm 0.0321$ & $0.53 \pm 0.055$ & $4.68 \pm 0.0321$ & $0.82 \pm 0.0264$ & $0.530 \pm 0.0454$ & $6.211 \pm 0.007$ & $4.79 \pm 0.0351$ & $4.82 \pm 0.0305$ \\
\hline $\mathrm{T}_{5}$ & $82 \pm 6.110$ & $4.29 \pm 0.0351$ & $0.50 \pm 0.043$ & $4.80 \pm 0.0305$ & $0.61 \pm 0.0251$ & $0.048 \pm 0.0055$ & $6.102 \pm 0.005$ & $5.06 \pm 0.0305$ & $5.28 \pm 0.0305$ \\
\hline $\mathrm{T}_{6}$ & $91 \pm 4.725$ & $5.81 \pm 0.0208$ & $0.72 \pm 0.055$ & $5.32 \pm 0.0360$ & $0.93 \pm 0.0152$ & $0.756 \pm 0.0040$ & $8.146 \pm 0.003$ & $5.71 \pm 0.0251$ & $5.82 \pm 0.0152$ \\
\hline $\mathrm{T}_{7}$ & $90 \pm 4.163$ & $6.22 \pm 0.0251$ & $0.68 \pm 0.068$ & $5.19 \pm 0.0351$ & $0.84 \pm 0.0305$ & $0.628 \pm 0.0046$ & $8.518 \pm 0.004$ & $5.52 \pm 0.0305$ & $5.60 \pm 0.0351$ \\
\hline
\end{tabular}

Values are mean \pm S.D of three samples

than uninoculated plants resulting in accumulation of more dry matter, $\mathrm{N}, \mathrm{P}$ and $\mathrm{K}$ in the stems and leaves (Nanthakumar and Veeraragavathatham, 2001).

Sole inoculation of Azospirillum sp. benefits plant growth and productivity by improving root development, mineral uptake and plant water relationship. In addition to nitrogen fixation, Azospirillum also produces growth promoting substances like IAA and GA and these hormones go a long way in enhancing the crop growth.

The source of IAA from Azospirillum might have increased the various endogenous hormonal levels in plant tissue, that was responsible for the enhanced pollen germination and tube growth, which ultimately increased the fruit set. The $\mathrm{N}$ availability and $\mathrm{N}$ content of the plants was enhanced due to the application of Azospirillum.

Azospirillum fixes the atmospheric nitrogen in the soil enhances the production of phytohormones like substances and increased uptake of nutrients such as phosphorus and potassium. The biological activity of the microorganisms would have helped the soil status to become a ready to serve zone for essential nutrients to plant's root system. Similar results were reported in 
Brinjal CV.GOB-1 (Chaudhari and Vihol, 2010), (Kamim, Zargar and Chatoo, 2002) and tomato (Premsekar and Rajashree) (Table 1 to Table 5).

\section{Discussion}

Today beneficial plant-microbe interactions that promote plant health and development have been the subject of considerable study in the field of agriculture particularly vegetable production which is our main nutritional diet in common food. Many plant-associated bacteria are well known for their capacity to confer plant growth promotion and to increase resistance towards various diseases as well as abiotic stresses.

Nevertheless, they often fail to confer these beneficial effects when applied in the field, which is often due to insufficient rhizo and endosphere colonization. A better understanding on how beneficial bacteria colonize different plant niches will not only result in increased knowledge on plant microbe interactions but will also lead to a more successful and reliable use of bacterial inoculants.

\section{Conclusion}

The present study was just an initiative in commonly use vegetable to identify more effective strains of plant growth promoting bacterial endophytes for further remarkable biotechnological potential in the field of environmental eco-friendly agriculture particularly vegetable production. Generally, a more comprehensive understanding of plant colonization by bacteria has to be developed in order to better predict how bacteria interact with plants and whether they are likely to establish themselves in the plant environment after field application as bio fertilizers.

\section{Acknowledgement}

The author wish to thank UGC-SAP, BSR Meritorious student Fellowship, New Delhi for financial support for this research work.

\section{References}

1. Baldiani, J.I., V.L.D. Baldiani, Seldin L. and J. Dobereiner, 1986. Characterization of Herbaspirillum seropedica gen. nov.sp. nov. a root associated nitrogen fixing bacterium. Int. J. Syst. Bacteriol., 36:86-93.

2. Berg, G., 2009. Plant microbe interactions promoting plant growth and health: Perspectives for controlled use of microorganisms in agriculture. Applied Microbiology and biotechnology 84,11-18.

3. Cavalcante, V.A. and J. Dobereiner, 1998. A new acid tolerant nitrogen fixing bacterium associated with sugarcane. PI. Soil, 108:23-31.

4. Christopher J. Beggs and Eckard Wellmann, 1985.
Analysis of light-controlled anthocyanin formation in coleoptiles of Zea mays L.: The role of UV-B, blue, red and far-red light Photochemistry and photobiology.Volume 41, Issue 4, Pages: 481-486,

5. Food safety and standard authority of India, Ministry of health and family welfare, Govt. Of India, New Delhi, 2012. Lab Manual 5: fssai, Manual methods of analysis of foods for fruits and vegetables.

6. Hardoim, P.R., van Overbeek, L.S.and J.D. Elsas, 2008. Properties of bacterial endophytes and their proposed role in plant growth. Trends in Microbiology 16,463-471.

7. Jagadish, LK., Krishnan, VV., Shenbhagaraman, R. and V. Kaviyarasan, 2009. Comparative study on the antioxidant, anticancer and antimicrobial property of Agaricus bisporus imbach before and after boiling. Afr. J. Biotechnol. 8, 654-661.

8. Lodewyckz C, Vangronsveld J. and F. Porteus, 2002. Endophytic bacteria and their potential applications. Crit. Rev. Plant Sci. 21:583-606.

9. Lowry OH, Rosenbrough NJ, Farr A. and R.J. Randall, 1951. Protein measurement with the Folin phenol reagent. J Biol.Chem; 193:265-75.

10. Lugtenberg, B.J.J., Dekkers, L. and G.V. Bloemberg, 2001. Molecular determinants of rhizosphere colonization by Pseudomonas. Annual Review of Phytopathology 39, 461-490.

11. Lutenberg, B. and F. Kamilova, 2009. Plant growth promoting rhizobacteria. Annual review of microbiology $63,541-556$.

12. Lutenberg. B.J.J., Dekkers, L. and G.V. Bloemberg. 2001. Molecular determinants of rhixzosphere colonization by Pseudomonas. Annual review of phytopathology 39, 461-490.

13. Nelson, N. A, 1944, Photometric adaptation of Somgyi method for determination of glucose. J. Biol. Chem., 135, 136-175.

14. Omaye, S.T., Turbull, T.P and H.C. Sauberchich, 1979. Selected methods for determination of ascorbic acid in cells, tissues and fluids. Methods Enzymol. 6: 3-11.

15. Reinhold-Hurek. B., T. Hurek, M. Gillis, B. Hoste, M. Vancanney, Kersters. K. and J. De Ley, 1993. Azoarcus gen. nov., nitrogen fixing probacteria associated with roots of kallar grass (Leptochloa fusca, (L). Kunth, and description of two species: Azoarcus indigens sp. nov. and Azoarcus communis sp. nov. Int. J. Syst. Bacteriol., 43:574-584).

16. Schloter, M., G. Kirchhof, U. Heinzmann, Dobereiner 
J. and A. Hartmann, 1994. Immunological studies of the wheat root colonization by Azospirillum brasilense strains $\mathrm{Sp} 7$ and $\mathrm{Sp} 245$ using strainspecific monoclonal antibodies. In: nitrogen fixation with non-legumes. Hegazi, N.A., Fayez, M., and Monib, M., Eds., pp. 291-297. The American University in Cairo Press, Cairo.

17. Shukla, V. and LB. Naik, 1993. Agro-techniques of solanaceous vegetables, in 'Advances in Horticulture', Vol. 5, Vegetable Crops, Part 1 (K. L. Chadha and G. Kalloo, eds.), Malhotra Pub. House, New Delhi, p. 365.

18. Steenhoudt, O. and J.Vanderleyden, 2000. Azospirillum, a free-living nitrogen-fixing bacterium closely associated with grasses: genetic, biochemical and ecological aspects. FEMS Microbiol. Rev. Oct; 24 (4):487-506.

19. Sturz, A.V. and J. Nowak, 2000. Endophytic communities of rhizobacteria and the strategies required to create yield enhancing associations with crops. Applied soil ecology 15, 183-190.

20. Takuma Gam and Sang Bae Ahn, 1991. Growthpromoting Azospirillum spp. isolated from the roots of several non-gramineous crops in Japan, Soil Science and Plant Nutrition, 37:3, 455-461.

21. Ulrich K, U Irich A. and D. Ewald, 2008. Diversity of endophytic bacterial community in popular growth under field conditions. FEMS Microbiol. Eco.163:169-180.

22. Weyens, N., van der Lelie, D., Taghavi, S. and J. Vangronsveld, 2009. Phytoremediation: Plant endophyte partnerships take the challenge. Current opinion in Biotechnology 20, 248-254.

23. Zhou, F.Y. and C.B. You, 1988. Interaction between diazotrophic bacteria Alcaligenes faecalis and host plant rice. Sci. Agric. Sinica, 21:7 13. 